stantially improve because a suitable tool for identifying the disorder has been developed. ${ }^{26}$ This simple screening questionnaire, which relies on self-reporting, has been specifically designed for use by the primary health care team during routine contacts and has been well validated in the community. ${ }^{27}$ The important topic of predicting at risk women before delivery is being addressed in current research.

Health care professionals should be aware of the possibility of problems in the mother-infant relationship arising because of postnatal depression. Postnatally depressed mothers are likely to be socially isolated and emotionally unsupported,,$^{28}$ and general practitioners, midwives, and health visitors are particularly well placed to provide support through their routine professional contacts - thereby dealing with the very deficits that are associated with maternal depression. Health professionals therefore need to pay attention to the emotional aspects of pregnancy, childbirth, and early infant care and to ensure that the topic is covered during training.

LYNNE MURRAY MRC Senior Fellow PETER J COOPER

Winnicott Research Unit, Department of Psychiatry, University of Cambridge, Cambridge CB1 2ES

ALAN STEIN Wellcome Trust Lecturer

Section of Child Psychiatry,

University of Oxford,

Park Hospital for Children,

Oxford OX3 7LQ

1 Rutter M. Parental mental disorder as a psychiatric risk factor. In: Hales RE, Frances AJ, eds. American Psychiatric Association Annual. Vol 6. Washington: American Psychiatric Press 1987:647-63.

2 Kumar R, Robson KM. A prospective study of emotional disorders in childbearing women Br f Psychiatry 1984;144:35-47.

3 Cooper PJ, Campbell EA, Day A, Kennerly H, Bond A. Non-psychotic psychiatric disorder after childbirth: a prospective study of prevalence, incidence, course and nature. $\mathrm{Br} f$ Psychiatry 1988:152:799-806.
4 Eisenberg RB. Auditory competence in early life. The roots of communicative behaviour. Baltimore: University Park Press, 1975.

Goren EG, Sarty M, Wu PYK. Visual following and pattern discrimination of face-like stimuli by newborn infants. Pediatrics 1975;56:544-9.

6 De Casper AJ, Fifer WP. Of human bonding: newborns prefer their mothers' voices. Science 1980;208:1174-6.

McFarlane A. Olfaction in the development of social preferences in the human neonate. In: Parentinfant interaction. Amsterdam: Elsevier, 1975:103-17. (Ciba Foundation Symposium No 33.)

8 Papousek H, Papousek M. Cognitive aspects of preverbal social interaction between human infants and adults. In: Parent-infant interaction. Amsterdam: Elsevier, 1975:241-69. (Ciba Foundation Symposium No 33 .

9 Brazelton TB, Tronick E, Adamson C, Als H, Wise S. Early mother-infant reciprocity. In: Parentinfant interaction. Amsterdam: Elsevier, 1975:137-54. (Ciba Foundation Symposium No 33.)

10 Murray L, Trevarthen C. Emotional regulation of interactions between 2 month olds and their mothers. In: Field TM, Fox NA, eds. Social perception in infants. New Jersey: Ablex, 1985 $177-97$.

11 Field T, Sandberg D, Garcia R, Vega Lahr N, Goldstein S, Guy L. Prenatal problems, postpartum depression and early mother-infant interactions. Developmental Psychology 1985;12:1152-6.

12 Cohn JF, Matias R, Tronick EZ, Connell D, Lyons-Ruth K. Face-to-face interactions of depressed mothers and their infants. In: Tronick EZ, Field T, eds. Maternal depression and infant disturbance. San Francisco: Jossey-Bass, 1986:31-44.

13 Murray L. The impact of maternal depression on infant development. In: de Cagno L, ed. Dal nascere al divenire nella realta e nella fantasia. Turin: Turin University, 1990:163-74.

14 Field T, Healy B, Goldstein S, et al. Infants of depressed mothers show "depressed" behaviour even with non-depressed adults. Child Dev 1988;59:1569-97.

15 Uddenberg N, Englesson I. Prognosis of postpartum mental disturbance: a prospective study of primiparous women and their four year old children. Acta Psychiatr Scand 1978;58:201-12.

16 Zajicek E, de Salis W. Depression in mothers of young children. Family Research Unit. Child Abuse Negl 1979;3:833-5.

17 Ghodsian M, Zajicek E, Wolkind S. A longitudinal study of maternal depression and child behaviour problems. I Child Psychol Psychiatry 1984;25:91-109.

18 Wrate RM, Rooney AC, Thomas PF, Cox JL. Postnatal depression and child development: three year follow up study. Brf Psychiatry 1985;146:622-7.

19 Williams H, Carmichael A. Depression in mothers in a multi-ethnic urban industrial municipality in Melbourne: aetiological factors and effects on infants and preschool children. $\mathcal{F}$ Child Psycho Psychiatry 1985;26:277-88.

20 Caplan H, Cogill S, Alexandra H, Robson K, Katz R, Kumar R. Maternal depression and the emotional development of the child. Brf Psychiatry 1989;154:818-23.

21 Stein A, Gath DH, Bucher J, Bond A, Day A, Cooper PJ. The relationship between postnatal depression and mother child interaction. Br f Psychiatry 1991;158:46-52.

22 Cogill S, Caplan H, Alexandra H, Robson K, Kumar R. Impact of postnatal depression on cognitive development in young children. BMF 1986;292:1165-7.

23 Ainsworth MD, Blehar MC, Waters E, Wall S. Patterns of attachment: a psychological study of the strange situation. New Jersey: Lawrence Earlbaum, 1978.

24 Henessy DA. Should health visitors also care for mothers? In: Hawthorne PJ, ed. Proceedings of the Royal College of Nursing Research Society annual conference. Nottingham: Nottingham University, 1985:46-9.

25 Holden JM, Sagovsky R, Cox JL. Counselling in a general practice setting: controlled study of health visitor intervention in treatment of postnatal depression. BMF 1989;298:223-6.

26 Cox AD, Holden JM, Sagovsky R. Detection of postnatal depression: development of the $10 \mathrm{item}$ Edinburgh postnatal depression scale. Br f Psychiatry 1987;150:782-6.

27 Murray L, Carothers AD. The validation of the Edinburgh postnatal depression scale on a community sample. $B r \mathcal{F}$ Psychiatry 1990;157:288-90.

28 O'Hara MW. Social support life events and depression during pregnancy and the puerperium. Arch Gen Psychiatry 1986;43.569-73.

29 Stein A, Cooper PJ, Day A, Campbell EA, Altham PEM. Social-adversity and perinatal complications: their relation to postnatal depression. BMF 1989;298:1073-4.

\title{
Brain, mind, insanity, and the law
}

\section{Sleepwalkers aren't insane}

Recently a defendant, who claimed to have been sleepwalking during an attack, was found not guilty by reason of insanity on a charge of wounding with intent. He was ordered to be admitted and detained in such hospital as the secretary of state should direct. Last month he appealed against the judge's ruling that sleepwalking was an insane automatism, but his case was dismissed. In giving the reserved judgment Lord Chief Justice Lord Lane said: "What the law regards as insanity for the purpose of these enactments may be far removed from what would be regarded as insanity by a psychiatrist."

This highlights yet again the difficulty that both the law and the medical profession face when a defendant chooses to plead not guilty by reason of automatism. Medically, an automatic act occurs in a confusional setting over which the individual has no control and for which he may have no memory. ${ }^{12}$ Automatisms result from brain dysfunction. A doctor's prime concern is for the patient rather than the consequences of the automatism. In law the main emphasis must be the protection of the public. It is these two different views that have led to the current complexity of the law on automatism and to the inadvertent stigmatisation of some offenders.
The law defines two types of automatism - sane and insane. Sane automatisms occur when the factor leading to the offence is external to the person. Legally, sane automatisms might include the jerking of a limb caused by a bee sting and after concussion or an injection of too much insulin. Automatisms due to diseases of the mind-insane automatisms-result from internal factors, inherent in the individual. Their range is very wide, including cerebral tumours, arteriosclerosis, epilepsy, personality factors, hysterical dissociative states, anxiety, and depression. Lord Justice Denning gave the reason for this distinction. "It seems to me that any mental disorder which has manifested itself in violence and is prone to recur is a disease of the mind. At any rate it is the sort of disease for which a person should be detained in hospital rather than be given an unqualified acquittal." Few doctors would disagree with these sentiments, but confusion arises because the law is using its own criteria of insanity.

The explanation lies in earlier judgments. In $\mathrm{R} v \mathrm{Kemp}^{+}$ Judge Devlin maintained that what constituted a disease of the mind was a question for the judge. He said, "The law is not concerned with the brain but with the mind. In the sense that mind is ordinarily used, the mental faculties of reason, 
memory, and understanding. If one read for disease of the mind, disease of the brain, it would follow that in many cases pleas of insanity would not be established because it could not be proved that the brain had been affected in any way, either by degeneration of the cells or in any other way. In my judgment the condition of the brain is irrelevant, and so is the question as to whether the condition of the mind is curable or incurable, transitory or permanent." With the greater availability of new imaging techniques, however, sustaining a distinction between "mind" and "brain" has become increasingly difficult.

One consequence of the legal view of insanity has been the unnecessary stigmatisation of certain groups - for example, people with epilepsy and sleepwalkers. Another is that defendants who fall within the category of having automatisms must (by act of parliament) be sent to a secure hospital under the control of the Home Secretary, while those who fall into the "sane" category walk out of court free. The judge has no option in this matter. For example, a defendant suffering from an islet cell tumour who offends in a confusional state must be sent to a secure hospital whereas if the confusional state resulted from injected insulin he or she would be given an absolute acquittal.
Although one sympathises with the lawyers' intentions, the law on these two points must be changed. The criminal justice bill now going through parliament provides an ideal opportunity for this. Firstly, the statutory disposal must be altered: the judge should be allowed to decide whether a defendant is given an absolute acquittal, goes to hospital, or is sent to a secure hospital. Secondly, the label of insanity should be abandoned. Both Lord Chief Justice Lane ${ }^{5}$ and Lord Diplock ${ }^{6}$ have said that it is natural to feel reluctance to attach the label of insanity to someone suffering from epilepsy or sleepwalking. Lord Lane agrees with Lord Diplock's view that "It does not lie within the power of the courts to alter it. Only parliament can do that. It has done so twice. It could do so again."

Consultant Psychiatrist,

P B C FENWICK

Institute of Psychiatry,

London SE5 8AF

1 Fenwick PBC. Automatism, medicine and the law. Psychoi Med [Monogr Suppl] 1990;17:1-27. 2 Fenton G. Epilepsy and automatism. Br f Hosp Med 1972;7:57-64

3 Bratty $v$ Attorney General for Northern Ireland. (1983) AC 386, 412 .

$4 \mathrm{R} v \operatorname{Kemp}(1957) 1 \mathrm{QB} 399,407$.

$5 \mathrm{R} v$ Burgess (1991). Unrevised judgment. Court of Appeal, 12 March.

$6 \mathrm{R} v$ Sullivan (1983). House of Lords Weekly Law Reports, July 8th.

\section{Health targets}

\section{Time to put the NHS back on course}

Tall ships will be visiting the United Kingdom this summer; so too perhaps tall stories. When navigating a dangerous passage in stormy weather helmsmen lash themselves to the wheel. But in these days of tempest in the NHS one might wonder whether the fleet is scattering in all directions because no course has been set. Organisations lacking a clear vision of their future and an obsession with winning are unlikely to survive, let alone succeed. ${ }^{1}$ All the more important then for those who sail in the NHS to know where they are going and to chart their progress accurately. Saying that we are concerned with improving health is not enough; we must set measurable objectives for health gain, monitor our progress, and take corrective action if we deviate from our course.

Next week the government is due to publish a consultative document on a national health strategy for England. According to William Waldegrave, Secretary of State for Health, it will give the NHS a clear set of goals against which to set its priorities and measure success. ${ }^{2}$ This should be applauded, not least because it will provide guidance for action by other government departments whose policies may have a profound impact on health - for example, on tobacco taxation, food supply, sex education, and housing. The draft strategy is likely to be based on the World Health Organisation's Targets for Health for All drawn up by WHO's European office. ${ }^{3}$ So far, more than 10 countries have followed WHO's lead in setting quantifiable health objectives.

Until this initiative the British government had been slow to set measurable health objectives with timetables, which has not gone unnoticed by the opposition parties. The Social and Liberal Democrats have advocated a comprehensive strategy of health promotion based on the WHO targets. Labour has gone further in its National Health initiative, and Robin Cook, Labour's shadow health secretary, has already put forward a set of priority targets. While England has taken its time, however, progress has been faster elsewhere in the
United Kingdom. Scotland has recently set some health targets for the under $65 \mathrm{~s}$ by the year $2000,{ }^{4}$ and Northern Ireland has published a consultative document.

Wales has by far the longest experience of this. In 1985 targets were set for the United Kingdom's first regional heart disease prevention programme, Heartbeat Wales. ${ }^{6}$ Then in January last year Peter Walker, as secretary of state, launched an ambitious strategy of "Health for All in Wales" to "take Wales into the 21 st century with a level of health on course to compare with the best in Europe." This included targets grouped under disease prevention, healthy lifestyles, health skills, and healthy environments. ${ }^{7}$ Spliced into this initiative has been a major development within the NHS itself. The director for Wales, John Wyn Owen, leads a health planning forum, which has devised a new framework for the NHS in Wales. With the active support of the new Secretary of State for Wales, David Hunt, a series of carefully constructed protocols for investment are being published for the 10 priority subjects (for example, cancer and cardiovascular disease). These will conclude with a series of targets across health care, ranging from prevention to rehabilitation. ${ }^{8}$

When considering our response to the government's new draft strategy we need to consider the effectiveness of the approach of setting targets as well as the specific proposals themselves. Could targets for health reorient the NHS towards outcome? Do they inspire, motivate, and encourage coordination and common purpose among health care workers and organisations? Can they engage other sectors at local and national levels? Will they mobilise support from ordinary people and communities?

Experience from the United States over more than a decade can help us here. In 1979 the Surgeon General published his seminal report Healthy People, ${ }^{9}$ which was expanded in 1980 with Objectives for the Nation, setting out 226 targets for 1990 in 15 priority subjects. ${ }^{10} \mathrm{~A}$ mid-course review was carried out, 